\title{
AJPH LETTERS AND RESPONSES
}

\section{THE PROTECTION TO WOMEN'S FUNDAMENTAL RIGHTS VIOLATED BY THE ZIKA VIRUS EPIDEMIC}

$\mathbf{T}$ he article by Teixeira et al. ${ }^{1}$ assumes a heroic tone describing the Brazilian response to the public health consequences of the Zika epidemic.

As the article demonstrates, the epidemic is concentrated among poor women from northeast Brazil, for whom there is no comprehensive sexual and reproductive health care available. Long-term contraceptive methods, which are culturally accepted by these women, are not offered by the public health system. Additionally, termination of pregnancy is illegal, and there is no novelty in the Brazilian social protection to include women and children affected by the epidemic.

I am leading a group who will demand that the Brazilian Supreme Court protect women's fundamental rights violated by the epidemic. The right to terminate a pregnancy will be included in our demands, but the ethical reasons for our petition are largely different from the authors' arguments: women have the right to decide to be freed of psychological torture imposed by the

Letters to the editor referring to a recent $A J P H$ article are encouraged up to 3 months after the article's appearance. By submitting a letter to the editor, the author gives permission for its publication in AJPH. Letters should not duplicate material being published or submitted elsewhere. The editors reserve the right to edit and abridge letters and to publish responses.

Text is limited to 400 words and 7 references. Submit online at www. editorialmanager.com/ajph. Queries should be addressed to the Editor-inChief, Alfredo Morabia, MD, PhD, at editorajph@qc.cuny.edu. epidemic. It is not the fetus's future impairments or the "extreme negative consequences for the families affected" that moves our demand, but the urgency to protect women's rights in the epidemic. $A$ JPH

Debora Diniz, PhD

\section{ABOUT THE AUTHOR}

Debora Diniz is professor at the Faculty of Law, University of Brasilia, Brasilia, Brazil, and is also a researcher with the Oswaldo Cruz Foundation, Rio de Janeiro, Brazil. Correspondence should be sent to Debora Diniz, Caixa Postal 8011, CEP 70673-970, Brasília DF, Brazil (e-mail: d.diniz@anis.org.br).Reprints can be ordered at http://www. ajph.org by clicking the "Reprints" link.

This letter was accepted April 23, 2016.

doi: 10.2105/AJPH.2016.303246

\section{REFERENCES}

1. Teixeira MG, da Conceição N Costa M, de Oliveira WK, Nunes ML, Rodrigues LC. The epidemic of Zika virus-related microcephaly in Brazil: detection, control, etiology, and future scenarios. Am J Public Health. 2016; 106(4):601-605.

\section{TEIXEIRA AND RODRIGUES RESPOND}

$\mathbf{W}$ e are grateful for this opportunity to reply to the letter by Diniz whose work in defense of women's rights is greatly admired. We would like to thank her for using our article to give context to the very important discussion of legalization of termination of pregnancy in Brazil, and for expanding it to include reproductive rights and social protection to women and children.

Our article was written very early in the epidemic, and although we had limited space, we felt it was important to raise the issue of reproductive choice. We note that in countries where terminations are legal (e.g., French Polynesia, United States, and Slovenia), more affected women choose to terminate.

We would like to support the application by the group that is led by Diniz to the Brazilian Supreme Court based on the human rights argument, demanding the right of a woman to be freed of the psychological torture imposed by the epidemic. We hope the application will be successful. AJPH

Maria G. Teixeira, $P h D$

Laura C. Rodrigues, $P h D$

\section{ABOUT THE AUTHORS}

Maria G. Teixeira is with the Instituto de Saude ColetivaUniversidade Federal da Bahia, Salvador, Brazil. Laura C. Rodrigues is with the London School of Hygiene and Tropical Medicine, London, England.

Correspondence should be sent to Laura C. Rodrigues,

London School of Hygiene and Tropical Medicine, Keppel St, LondonWC1E7HT, England (e-mail: laura.rodrigues@

lshtm.ac.uk). Reprints can be ordered at http://www.ajph.org by clicking the "Reprints" link.

This letter was accepted April 23, 2016.

doi: $10.2105 /$ AJPH.2016.303249

\section{CONTRIBUTORS}

Both authors contributed equally to this letter. 